\title{
EFFECT OF DIFFERENT LEVELS OF PHOSPHORUS INPUT ON PHYTOPLANKTON PRODUCTIVITY IN LIMED ACID SULFATE SOILS FISHPOND
}

\author{
Abdul Karim Gaffar ${ }^{*}$
}

\begin{abstract}
One of problems of building fishponds in acid sulfate soil areas is their poor response to fertilization. An experiment to assess the effect of different doses of triple super phosphate (TSP) on phytoplankton productivity in acid sulfate soil fishponds has been conducted for one month using 15 earthen ponds of $20 \mathrm{~m}^{2}$ each. Prior to fertilizer application the ponds were limed at $1.35 \mathrm{~kg} / \mathrm{m}^{2}$ and urea fertilizer was applied at $12 \mathrm{~g} / \mathrm{m}^{2}$. The results showed that there were positive relationships between doses of TSP applied and chlorophyll- $a$ concentrations. Fishponds receiving TSP at a rate of $28 \mathrm{~g} / \mathrm{m}^{2}$ had mean chlorophyll- $a$ concentrations of $90.76 \mathrm{mg} / \mathrm{m}^{3}$. compared to $4.90 \mathrm{mg} / \mathrm{m}^{3}$ in control ponds.
\end{abstract}

\section{KEYWORDS: Acid sulfate soils; freshwater fishpond; phosphorus, chlorophyll-a.}

\section{IN'TRODUC'TION}

Phosphorus is a key nutrient in pond fertilization (Boyd and Musig, 1981), because its natural concentration in pond water is usually too low to support abundant phytoplankton populations (Boyd, 1982). Several types of phosphorus fertilizers are commonly used in fishponds (Boyd, 1979).

Inorganic phosphate added to fish ponds in fertilizers is removed from the water primarily by phytoplankton, bacteria and sediment (Boyd, 1979). Phosphate adsorption by pond soil increases with increasing clay content, exchange acidity, exchangeable iron, aluminum and calcium, but decreases with increasing organic matter and soil pH (Pahila, 1990; Shresta, 1994).

Fishponds built on acid sulfate soils require extra phosphorus input as the prevalence of acid cations effectively immobilizes phosphorus.

Fertilizers are applied to fishponds to increase inorganic nutrient concentrations thereby supporting greater phytoplankton growth. The growth rate of an alga will decline if the concentration of a given nutrient drops below that supporting an uptake rate sufficient to maintain the existing growth rate (Darley, 1982).

The objective of this experiment is to evaluate the effects of different doses of phosphate fertilizer, plus a constant amount of urea, in the enhancement of phytoplankton productivity in limed acid sulfate soil fishponds.

\section{MATERIALS AND METHODS}

\section{Pond Preparation}

Fifteen ponds of $20 \mathrm{~m}^{2}$ each were used. Ponds were deacidified before fertilizer application by repeated water inundation and draining, followed by liming at a rate of $1.35 \mathrm{~kg} / \mathrm{m}^{2}$. Lime $\left(\mathrm{CaCO}_{3}\right)$ was incorporated and mixed with soil mass to $10 \mathrm{~cm}$ depth.

\footnotetext{
*) Researcher of the Palembang Research Station for Freshwater Fisheries
} 


\section{Fertilization}

The ponds were inundated with water from a reservoir canal 2 days after liming, and then fertilized 3 days after inundation. The fertilizers were dissolved in water in a plastic bucket and splashed over the pond surface.

The experiment was arranged in a randomized design consisting of 5 levels with single applications of 'TSP'

Control: $\quad 0.0 \mathrm{~g} \mathrm{TSP} / \mathrm{m}^{2}+12.0 \mathrm{~g}$ urea $/ \mathrm{m}^{2}$

P1: $\quad 3.5 \mathrm{~g} \mathrm{TSP} / \mathrm{m}^{2}+12.0 \mathrm{~g}$ urea $/ \mathrm{m}^{2}$

P2: $\quad$ $\quad$.0g TSP $/ \mathrm{m}^{2}+12.0 \mathrm{~g}$ urea $/ \mathrm{m}^{2}$

P3: $\quad 14.0 \mathrm{~g} \mathrm{TSP} / \mathrm{m}^{2}+12.0 \mathrm{~g}$ urea $/ \mathrm{m}^{2}$

P4: $\quad 28.0 \mathrm{~g} \mathrm{TSP} / \mathrm{m}^{2}+12.0 \mathrm{~g}$ urea $/ \mathrm{m}^{2}$.

Each treatment had 3 replications.

Pond water samples were collected with a 5-cm diameter PVC pipe column sampler for analysis of soluble orthophosphate twice a week, and for chlorophyll-a measurement in every 2 days. Total alkalinity, $\mathrm{pH}$, and $\mathrm{NH}_{4}$ $\mathrm{N}$ were measured weekly.

The experimental duration was one month.

Data were analyzed by one-way analysis of variance and regression analysis using Statgrapics statistical software packages.

\section{RESUITS}

Mean values of chlorophyll-a, alkalinity, $\mathrm{pH}$, soluble reactive phosphorus (SRP) and $\mathrm{NH}_{4}-\mathrm{N}$ in pond water during the one month of experimental period are shown in Table 1.

There were significant effects of the different TSP inputs on chlorophyll-a concentrations ( $p<0.05)$, on SRP concentrations $(p<$ $0.05)$, and on $\mathrm{NH}_{4}-\mathrm{N}$ concentrations ( $\mathrm{p}<$ $0.05)$, but, not water $\mathrm{pH}$ or alkalinity $(\mathrm{p}>$ $0.05)$.

As shown in Table 1, the highest concentration of $\mathrm{NH}_{4}-\mathrm{N}$ was found in the control ponds while the lowest concentration was found in ponds treated with $28.0 \mathrm{~g} \mathrm{TSP} / \mathrm{m}^{2}$.

There was a linear correlation between SRP concentrations and levels of TSP input, shown by the following equation:

$$
\begin{aligned}
& Y=-0.032+0.032 X \\
& r^{2}=0.98,(p<0.01)
\end{aligned}
$$

where: $Y=\operatorname{SRP}(\mathrm{mg} / \mathrm{L})$, and $X=\operatorname{TSP}\left(\mathrm{g} / \mathrm{m}^{2}\right)$.

The different levels of TSP input clearly resulted in different phytoplankton biomass as indicated by the chlorophyll-a concentrations.

Table 1. Mean value of chlorophyll- $\alpha$, alkalinity, $\mathrm{pH}$, SRP, and $\mathrm{NH}_{4}-\mathrm{N}$ in pond water during one month of experimental period related to different TSP input.

\begin{tabular}{|c|c|c|c|c|c|}
\hline TSP input & $\begin{array}{c}\text { Chlorophyll- } a \\
\left(\mathrm{mg} / \mathrm{m}^{3}\right)\end{array}$ & $\begin{array}{c}\text { Alkalinity } \\
\left(\mathrm{mg} \mathrm{Ca}^{2} \mathrm{CO}_{3} / \mathrm{L}\right)\end{array}$ & $\mathrm{pH}$ & $\begin{array}{l}\mathrm{SRP} \\
(\mathrm{mg} / \mathrm{L})\end{array}$ & $\begin{array}{l}\mathrm{NII}_{4}-\mathrm{N} \\
(\mathrm{mg} / \mathrm{L})\end{array}$ \\
\hline Control & $4.90 \pm 0.46^{\mathrm{a}}$ & $65.42 \pm 6.01^{\mathrm{a}}$ & $8.3 \pm 0.06^{\mathrm{a}}$ & $0.01 \pm 0.003^{\mathrm{a}}$ & $3.06 \pm 0.31^{\mathrm{a}}$ \\
\hline$\left(3.5 \mathrm{~g} / \mathrm{m}^{2}\right)$ & $12.85 \pm 0.23^{b}$ & $63.33 \pm 3.79^{\mathrm{a}}$ & $8.2 \pm 0.18^{\mathrm{a}}$ & $0.05 \pm 0.006^{\mathrm{a}}$ & $2.87 \pm 0.20^{a}$ \\
\hline$\left(7.0 \mathrm{~g} / \mathrm{m}^{2}\right)$ & $28.40 \pm 3.61^{\prime}$ & $67.50 \pm 9.46^{\mathrm{a}}$ & $8.4 \pm 0.30^{\mathrm{a}}$ & $0.17 \pm 0.034^{\mathrm{b}}$ & $2.07 \pm 0.51^{\mathrm{ab}}$ \\
\hline$\left(14 \mathrm{~g} / \mathrm{m}^{2}\right)$ & $46.63 \pm 1.35^{\mathrm{d}}$ & $70.83 \pm 5.32^{a}$ & $8.5 \pm 0.25^{a}$ & $0.42 \pm 0.041^{\circ}$ & $1.87 \pm 0.14^{b c}$ \\
\hline $\mathrm{P} 4 \quad\left(28 \mathrm{~g} / \mathrm{m}^{2}\right)$ & $90.76 \pm 2.68^{\mathrm{d}}$ & $83.75 \pm 11.8^{a}$ & $8.5 \pm 0.12^{a}$ & $0.86 \pm 0.020^{\mathrm{d}}$ & $1.46 \pm 0.16^{\prime}$ \\
\hline
\end{tabular}

$($ Mean $\pm 1 \mathrm{SE} ; \mathrm{N}=12)$

Values with the same alphabet in same column indicate no significant different at $95 \%$ confident limit. 
The concentration of SRP decreased with time (Figure 1). In ponds receiving $3.5 \mathrm{~g}$ TSP/ $\mathrm{m}^{2}$ the SRP was undetectable after 18 days, whereas in ponds receiving $28.0 \mathrm{~g} \mathrm{TSP} / \mathrm{m}^{2}$ the $\mathrm{SRP}$ was available until the end of experiment.

Different levels of TSP input to pond water clearly resulted in different phytoplankton biomass as indicated by the chlorophyll- $a$ concentration. Higher level of TSP input gave a greater chlorophyll-a concentration. P4 with TSP input $28.0 \mathrm{~g} / \mathrm{m}^{2}$ had a mean chlorophyll-a concentration of $90.76 \mathrm{mg} / \mathrm{m}^{3}$. while P1 with TSP input $3.5 \mathrm{~g} / \mathrm{m}^{2}$ had a mean chlorophyll-a concentration of $12.85 \mathrm{mg} / \mathrm{m}^{3}$ $(\mathrm{p}<0.05)$.

There were different pattern of phytoplankton growth among treatments. In ponds receiving higher TSP input $\left(28.0 \mathrm{~g} / \mathrm{m}^{2}\right)$ phytoplankton growth slightly increased in the first and second week and sharply increased in the third week and then declined at the end of the fourth week. In ponds receiving low level of TSP input $\left(3.5 \mathrm{~g} / \mathrm{m}^{2}\right)$ the phytoplankton growth slightly increased in the first week but declining in the second week until the end of experiment.

Table 2 and Figure 2 show that within the first week after fertilization any levels of TSP input gave significantly higher chlorophyll-a concentration compared to controls with no TSP input. Ponds receiving highest level of TSP (P4) had significantly higher chlorophylla concentration than in pords receiving the lowest rate of TSP (P1). However, there were no significant difference in chlorophyll- $a$ concentration between $\mathrm{P} 1, \mathrm{P} 2$ and $\mathrm{P} 3$, and between P2, P3 and P4.

In the second week chlorophyll- $a$ concentration in P1 was significantly lower than in P2, P3 and P4, and there was a significantly lower concentration of chlorophyll- $a$ in P2 compared to $\mathrm{P} 4$.
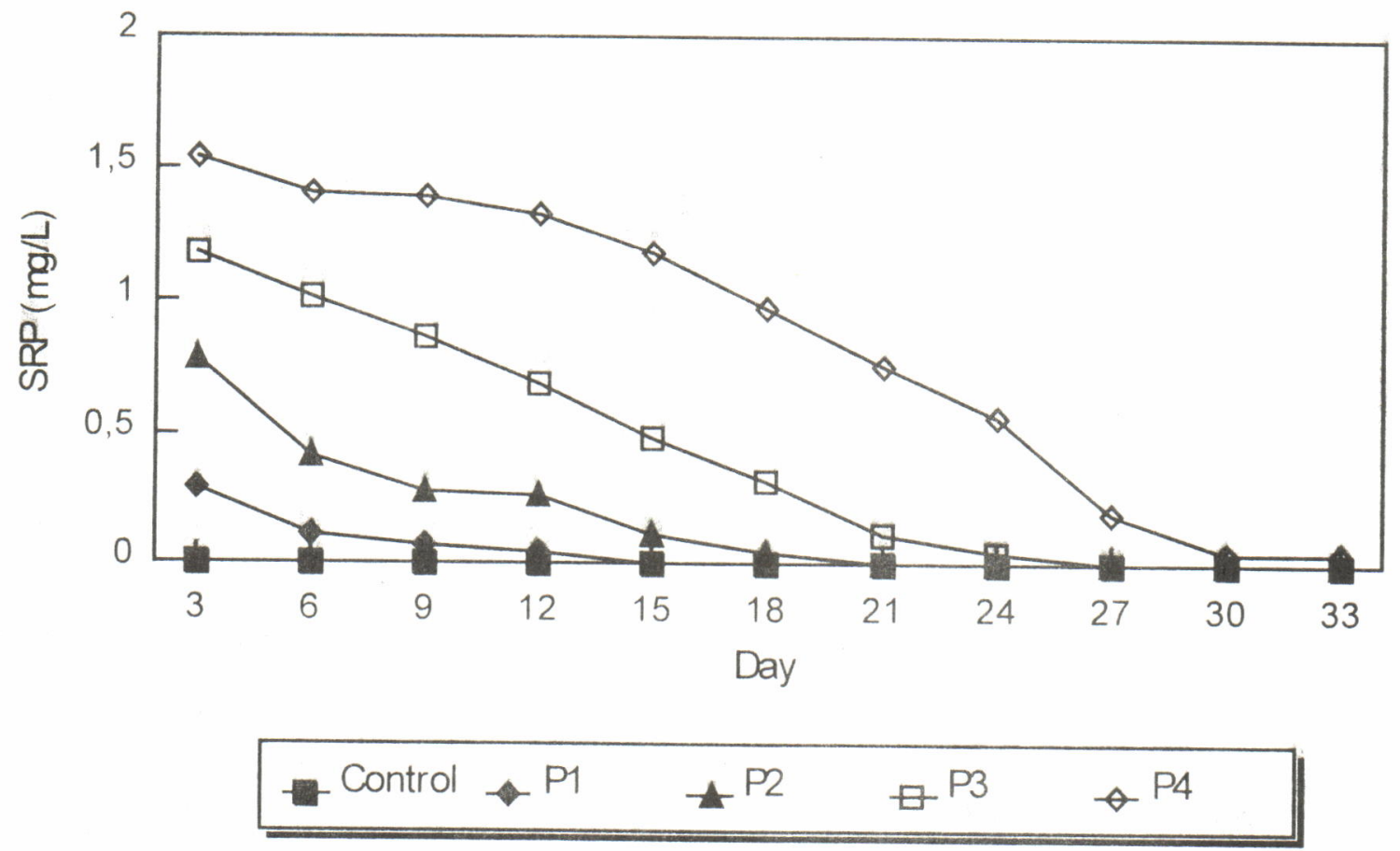

Figure 1. Souluble irthophosphate concentration in pond water during one month of experimental period related to different TSP input. 
Table 2. Chlorophyll-a concentrations $\left(\mathrm{mg} / \mathrm{m}^{3}\right)$ in ponds received different levels of TSP fertilizer base on weekly measurement.

$($ Mean \pm 1 SE $; n=3)$

\begin{tabular}{|c|c|c|c|c|c|}
\hline & \multirow[t]{2}{*}{ TSP } & \multicolumn{4}{|c|}{ Input (Week) } \\
\hline & & 1 & 2 & 3 & 4 \\
\hline \multicolumn{2}{|c|}{ Control } & $3.12 \pm 0.56^{\mathrm{a}}$ & $2.12 \pm 0.49^{\mathrm{a}}$ & $4.23 \pm 1.56^{\mathrm{a}}$ & $4.67 \pm 0.48^{\mathrm{a}}$ \\
\hline P1 & $\left(3.5 \mathrm{~g} / \mathrm{m}^{2}\right)$ & $13.58 \pm 0.87^{b}$ & $13.13 \pm 2.12^{a}$ & $9.46 \pm 1.94^{\mathrm{a}}$ & $11.78 \pm 0.22^{\mathrm{a}}$ \\
\hline $\mathrm{P} 2$ & $\left(7.0 \mathrm{~g} / \mathrm{m}^{2}\right)$ & $17.25 \pm 1.31^{\mathrm{bc}}$ & $30.27 \pm 4.71^{\mathrm{b}}$ & $34.94 \pm 11.05^{\mathrm{b}}$ & $31.59 \pm 12.54^{\mathrm{bc}}$ \\
\hline P3 & $\left(14 \mathrm{~g} / \mathrm{m}^{2}\right)$ & $16.69 \pm 3.21^{\mathrm{bc}}$ & $41.83 \pm 0.73^{b}$ & $78.67 \pm 0.78^{\circ}$ & $53.84 \pm 12.57^{\circ}$ \\
\hline P4 & $\left(28 \mathrm{~g} / \mathrm{m}^{2}\right)$ & $22.14 \pm 1.64^{\circ}$ & $42.72 \pm 6.35^{\circ}$ & $143.21 \pm 5.09^{\mathrm{d}}$ & $169.84 \pm 12.64^{d}$ \\
\hline
\end{tabular}

Sharing same alphabet in same column indicate no significant difference at $95 \%$ confident limit.

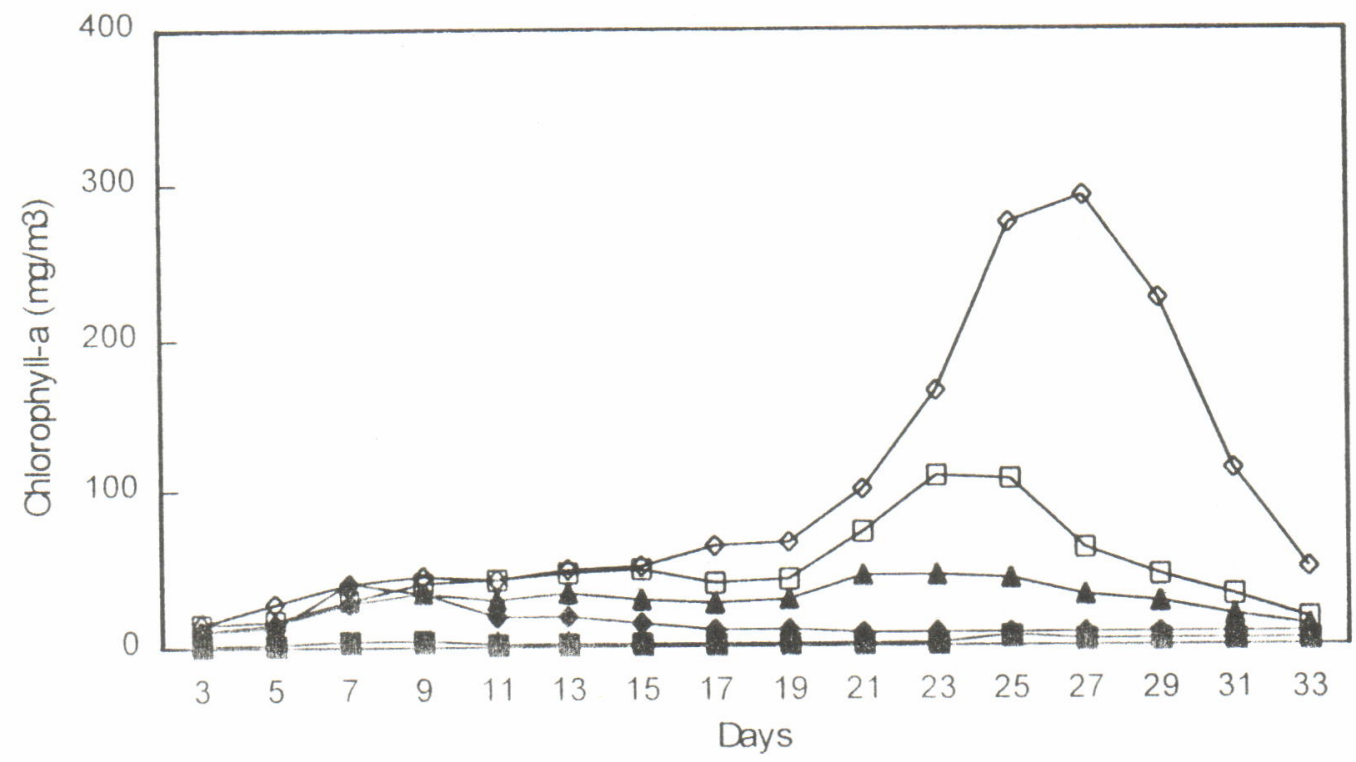

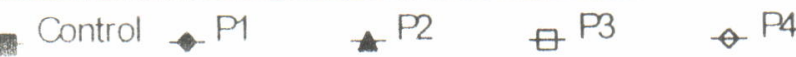

Figure 2. Chlorophyll-a concentration in pond water during one months of experimental period related to different level of TSP input.

In the third week the ponds treated with $28.0 \mathrm{~g} \mathrm{TSP} / \mathrm{m}^{2}$ (P4) have chlorophyll-a concentration distinctly higher than other treatments. On the other hand, the ponds treated with $3.5 \mathrm{~g} \mathrm{TSP} / \mathrm{m}^{2}$ had an extremely low chlorophyll-a concentration.

In the fourth week phytoplankton growth in all ponds but $\mathrm{P} 4$ was slowing down.
Relationship between TSP input $\left(\mathrm{g} / \mathrm{m}^{2}\right)$ and chlorophyll-a concentration in pond water is presented in following the equation:

$$
\begin{aligned}
& \mathrm{Y}=2.90+3.268 \mathrm{X} \\
& \mathrm{r}^{2}=0.99,(\mathrm{p}<0.01)
\end{aligned}
$$

where: $\mathrm{Y}=$ chlorophyll $-\alpha$ concentration $\left(\mathrm{mg} / \mathrm{m}^{3}\right)$. and $X=$ TSP input $\left(\mathrm{g} / \mathrm{m}^{2}\right)$. 
The highest concentration of $\mathrm{NH}_{4}-\mathrm{N}$ was found in control ponds while the lowest concentration was found in ponds treated with $28.0 \mathrm{~g} \mathrm{TSP} / \mathrm{m}^{2}$.

\section{DISCUSSION}

Phosphorus has been recognized as a major limiting nutrient regulating the water bodies (Jana and Sahu, 1994; Boyd and Musig, 1981). However, there is some evidence suggesting that nitrogen is important in regulating primary productivity and algal biomass in pond waters (Yusoff and McNabb, 1989)

Algal cell contains $\mathrm{N}$ and $\mathrm{P}$ in ration 15-16 to 1 (Stum and Morgan, 1974), but Boyd (1990) stated that the nitrogen to phosphorus ratios in fertilizer application rates do not resemble nitrogen to phosphorus ratios in algal cell, because in ponds bacteria and bluegreen algae are able to fix nitrogen from atmosphere and rates of loss from water of nitrogen and phosphorus applied in fertilizer was differ.

Loss of soluble orthophosphate from pond water as described by Boyd and Musig (1981) were taken up by phytoplankton and bacteria, and absorbed by pond sediment. Phosphorus absorbed by the sediment of acid soil could be the major parts of phosphorus loss from pond water. The pond soil which was high in clay content, and high in iron and aluminum was conducive for phosphate fixation.

The findings in this study shows that soluble orthophosphate existed in pond water for longer period in ponds receive higher level of TSP input, therefore, by a single application higher level of TSP gave a greater $\mathrm{P}$ availability to phytoplankton. Increasing TSP input resulted in proportional increase in chlorophyll-a concentrations. Ponds which was treated with $28 \mathrm{~g} \mathrm{TSP} / \mathrm{m}^{2}\left(0.19 \mathrm{~g} \mathrm{P} / \mathrm{n}^{2} /\right.$ day) with $\mathrm{N}: \mathrm{P}$ ratio $1: 1$ produced mean chlorophyll-a concentrations of $90.8 \mathrm{mg} / \mathrm{m}^{3}$, whereas ponds which treated with $14 \mathrm{~g}$ TSP/ $\mathrm{m}^{2} /$ day $\left(0.10 \mathrm{~g} \mathrm{P} / \mathrm{n}^{2} /\right.$ day) with $\mathrm{N}: \mathrm{P}$ ratio $2: 1$, produced $46.63 \mathrm{mg} / \mathrm{m}^{3}$.

This finding was in agreement with Boyd (1990) who stated that phytoplankton productivity is positively correlated with nutrient concentration. Knud Hansen et al. (1993) also found that there was a linear relationship between TSP-P input and net fish yield. However, Ball (1949) as cited by Boyd (1990) found that the closer fish fed to the base of food chain, the more their yield was increased by fertilization.

With a natural concentration of phosphorus in control ponds, the urea input fail to enhance phyto-plankton growth, otherwise increasing phosphorus in combination with urea gave significantly higher phytoplankton growth. This finding were complementary with the results of Yusoff and McNabb (1989) in Malaysia. They found that phytoplankton biomass was to be higher in ponds receiving 'TSP + Urea than that in ponds treated with TSP only.

Low concentration of $\mathrm{NH}_{4}-\mathrm{N}$ in ponds receiving high level of TSP showed a higher $\mathrm{N}$ consumption in ponds, and greater phytoplankton biomass.

\section{CONCLUSION}

Fishpond built in acid sulfate soils after deacidified by application of lime was suffering in low plant nutrients, especially phosphorus. Phytoplankton have poor growth in ponds fertilized by urea only, whereas addition TSP fertilizer give a strong response to increase phytoplankton biomass. Under the present condition there was a linear relationship between TSP input and phytoplankton biomass. In practice, fertilization with $0.2 \mathrm{~g}$ $\mathrm{P} / \mathrm{m}^{3} /$ day or more with $\mathrm{N}$ to $\mathrm{P}$ ratio $1: 1$ would be suitable for limed acid sulfate soils fishpond. 


\section{REFERENCES}

Boyd, C.F. 1979. Water Quality in Warmwater Fish Ponds. Auburn University. Auburn. 359 pp.

Boyd, C.E. 1982. Water Quality Management for Pond Fish Culture. Development in Aquaculture and Fisheries Science. Vol 9. Elsevier Scientific Publishing Company. Amsterdam. $318 \mathrm{pp}$.

Boyd, C.E. 1990. Water Quality in Ponds for Aquaculture. Auburn University. Auburn. 482 pp.

Bovd, C.E. and Y. Musig. 1981. Orthophosphate uptake by phytoplankton and sediment. Aqua culture. 22:165-173.

Darley. W.M. 1982. Algal biology: a physiological approach. Blackwell Scientific Publications. Oxford. $168 \mathrm{pp}$.
Jana, B.B. and S.N. Sahu. 1994. Effect of frequency of rock phosphate application in carp culture. Aquaculture. 122:313-321.

Knud-Hansen, C.F., Batterson, T.R. and C.D. MeNabb. 1993. The role of chicken manure in the production of Nile tilapia,Oreochromis niloticus L. Aquaculture and Fisheries Management. 24:483-493.

Pahila, I.G. 1990. Soluble phosphorus in relation to phosphorus fertilization of Lab-lab (benthic algae) in brackishwater ponds. in. Hirano, $R$ and I.Hanyu (Ed) The Second Asian Fisheries Forum.AFS. Manila. p.189-192.

Shresta, M.K. 1994. Dynamics and recovery of phosphorus in mud of fertilized fish ponds. I).Tech.Sc Dissertation. AIT. Bangkok.

Stumn. W. and J.J. Morgan. 1970. Aquatic Chemistry. Wiley-Interscience. New York. 583 pp.

Yusoff, F.M. and C.D. McNabb. 1989. Effects on nutrients availability on primary productivity and fish production in fertilized tropical ponds. Aquaculture, 78:3030-319. 